\title{
Effect of long-term exposure of SH-SY5Y cells to morphine: a whole cell proteomic analysis Jérémie Neasta ${ }^{1}$, Sandrine Uttenweiler-Joseph ${ }^{2}$, Karima Chaoui ${ }^{1}$, Bernard Monsarrat ${ }^{2}$, Jean-Claude Meunier ${ }^{1}$ and Lionel Moulédous*1
}

\begin{abstract}
Address: ${ }^{1}$ Unité Mécanismes d'action des substances opioïdes, Institut de Pharmacologie et de Biologie Structurale, Centre National de la Recherche Scientifique UMR 5089, 205 route de Narbonne, 31077 Toulouse cedex 04, France and 2Unité Spectrométrie de masse et structure des biomolécules, Institut de Pharmacologie et de Biologie Structurale, Centre National de la Recherche Scientifique UMR 5089, 205 route de Narbonne, 31077 Toulouse cedex 04, France

Email: Jérémie Neasta - neasta@ipbs.fr; Sandrine Uttenweiler-Joseph - sandrine.uttenweiler@ipbs.fr; Karima Chaoui - karima.chaoui@ipbs.fr; Bernard Monsarrat - bernard.monsarrat@ipbs.fr; Jean-Claude Meunier - jcm@ipbs.fr; Lionel Moulédous* - lionel.mouledous@ipbs.fr

* Corresponding author
\end{abstract}

Published: 2I December 2006

Proteome Science 2006, 4:23 doi:10.1 I86/1477-5956-4-23

This article is available from: http://www.proteomesci.com/content/4/I/23

(C) 2006 Neasta et al; licensee BioMed Central Ltd.

This is an Open Access article distributed under the terms of the Creative Commons Attribution License (http://creativecommons.org/licenses/by/2.0), which permits unrestricted use, distribution, and reproduction in any medium, provided the original work is properly cited.
Received: 19 September 2006

Accepted: 21 December 2006

\begin{abstract}
Background: Opiate addiction reflects plastic changes that endurably alter synaptic transmission within relevant neuronal circuits. The biochemical mechanisms of these adaptations remain largely unknown and proteomics-based approaches could lead to a broad characterization of the molecular events underlying adaptations to chronic drug exposure.

Results: Thus, we have started proteomic analyses of the effects of chronic morphine exposure in a recombinant human neuroblastoma SH-SY5Y clone that stably overexpresses the $\mu$-opioid receptor. Cells were treated with morphine for 6, 24 and 72 hours, the proteins were separated by 2-D gel electrophoresis and stained with Coomassie blue, and the protein map was compared with that obtained from untreated cells. Spots showing a statistically significant variation were selected for identification using mass spectrometric analyses.

Conclusion: A total of 45 proteins were identified, including proteins involved in cellular metabolism, cytoskeleton organization, vesicular trafficking, transcriptional and translational regulation, and cell signaling.
\end{abstract}

\section{Background}

Opiate addiction, a pathological form of learning and memory associated with repeated drug use or administration, reflects neuronal adaptive/plastic changes that endurably alter synaptic transmission within relevant circuits in the central nervous system [1-4]. The biochemical mechanisms underlying the functional and structural adaptations to chronic opiate exposure remain largely unknown. Elucidating them in details is important, as this is expected to reveal novel pharmacological strategies for preventing formation and/or expression of dependence, with potential benefits for the treatment of chronic pain and addiction.

The biochemical mechanisms of drug dependence have begun to be examined globally by using DNA microarrayand/or proteomics-based approaches. Thus, DNA microarray-based approaches have been used in order to study gene expression induced by drugs of abuse [5], including opiates $[6,7]$, but interpretation of the results is limited - 
mRNA levels do not necessarily reflect proteins levels [8] - and no information about post-transcriptionally modified proteins is provided. In principle, proteomics-based approaches could lead to a much broader characterization of the molecular events underlying drug dependence. Yet, the successful application of differential proteomics to identify drug-induced protein changes in the central nervous system represent a technical challenge because of its cellular heterogeneity [9].

Obviously, sample heterogeneity is much less of a problem in cultured clonal cell lines than in nerve tissue. Thus, we have started proteomic analyses of the effects of chronic morphine exposure in a recombinant human neuroblastoma SH-SY5Y clone that stably overexpresses the $\mu$-opioid (MOP) receptor. Wild-type SH-SY5Y cells express low levels of MOP receptor, and even lower (3- to 4 -fold) levels of delta opioid (DOP) receptor [10], and are only poorly responsive to both acute and long-term morphine treatment [11]. In marked contrast, in MOP receptor-overexpressing cells, acute morphine is much more potent and efficacious in inhibiting forskolin-elicited production of cAMP, and chronic morphine induces a higher degree of adenylate cyclase sensitization, a hallmark of opiate dependence, than in the parent (wild type) cells [11]. The dramatically increased responsiveness of MOPoverexpressing over wild-type cells is an indication that the observed effects are MOP receptor- rather than DOP receptor-mediated. The cells were treated with morphine for 6,24 and 72 hours, the proteins were separated by 2 D electrophoresis (2-DE) and stained with colloidal Coomassie blue, and the protein map was compared with that obtained from untreated cells. Spots showing a statistically significant variation were selected for identification using a combination of MALDI-TOF MS (matrix-assisted laser desorption/ionization time of flight mass spectrometry) and nanoLC-ESI-Q-TOF MS/MS (liquid-chromatography electrospray ionization quadrupole time of flight) analyses. A total of 45 proteins were found to have varied in abundance in the course of long-term exposure to morphine, including proteins involved in cellular metabolism, cytoskeleton organization, vesicular trafficking, transcriptional and translational regulation, and cell signaling.

\section{Results}

Figure 1 shows a representative bi-dimensional map of the proteome of untreated (control) neuroblastoma SHSY5Y cells. Colloidal Coomassie blue protein staining, followed by automatic feature detection and manual editing enabled visualization of about 950 individual spots on a 2-D gel.

The protein map of neuroblastoma cells having been treated with $1 \mu \mathrm{M}$ morphine for 6 hours was compared with that of untreated cells. A $6 \mathrm{~h}$ treatment with morphine was selected since such treatment was previously shown to elicit nearly maximum sensitization of adenylate cyclase, an index of opiate dependence, in these cells [11]. As shown on Figure 1, the protein pattern from $6 \mathrm{~h}$-treated cells was globally very similar to that of control cells. After image analysis, the abundance of each spot was estimated relative to the abundance of all spots in the gel (see Methods). Four control gels were matched with four $6 \mathrm{~h}$ morphine-treatment gels and the spots showing a statistically significant variation in relative abundance (Student $t$ test, $p<0.05$ ) were selected for identification by mass spectrometry. Eighteen spots displayed such significant variation: 11 spots were upregulated by a factor 1.22 to 2.03 following morphine treatment, while 7 spots were downregulated by a factor 0.35 to 0.75 . These spots were cut from a gel, digested by trypsin and analyzed by peptide mass fingerprinting using MALDI-TOF mass spectrometry. When peptide mass fingerprinting data was not sufficient for confident identification, trypsin digests were also analyzed using nanoLC-ESI-MS/MS. The combination of these two methods enabled the unambiguous identification of 18 proteins whose name, accession number, change in relative abundance and MS data are summarized on Table 1. Spot numbers in this table refer to the ones in Figure 2, which depicts the location of every spot that was identified in this study on a representative 2D gel. Spot 11 could not be identified while spot 24 contained a mixture of 2 proteins.

We next examined the proteome effects of exposing the neuroblastoma cells to morphine $(1 \mu \mathrm{M})$ for longer periods of time, i.e. 24 and 72 hours. Twenty one spots were found to display a significant variation in relative abundance after a $24 \mathrm{~h}$ morphine treatment: 11 spots were upregulated by a factor 1.18 to 1.84 , whilst 10 spots were downregulated by a factor 0.45 to 0.84 . Among these, 18 spots could be attributed to one protein, and 3 spots contained a mixture of 2 proteins (Table 2). 2 spots with similar molecular weights but different pIs contained the same protein ( $\alpha$-enolase). The relative volume of these 2 spots varied in opposite direction after morphine treatment suggesting a change in post-translational modification, possibly phosphorylation. Twenty-five spots displayed a significant variation in relative abundance after a $72 \mathrm{~h}$ morphine treatment: 5 spots were upregulated by a factor 1.1 to 1.79 , whilst 20 spots were downregulated by a factor of 0.45 to 0.84 . Among these, 21 could be attributed to one protein, 2 contained a mixture of 2 proteins, and 2 could not be identified (Table 3 ).

The pattern of morphine-responsive proteins was clearly dependent upon the duration of exposure of the cells to morphine. In fact, only 8 proteins were found to be significantly regulated at 2 or 3 time points. Vacuolar ATP syn- 


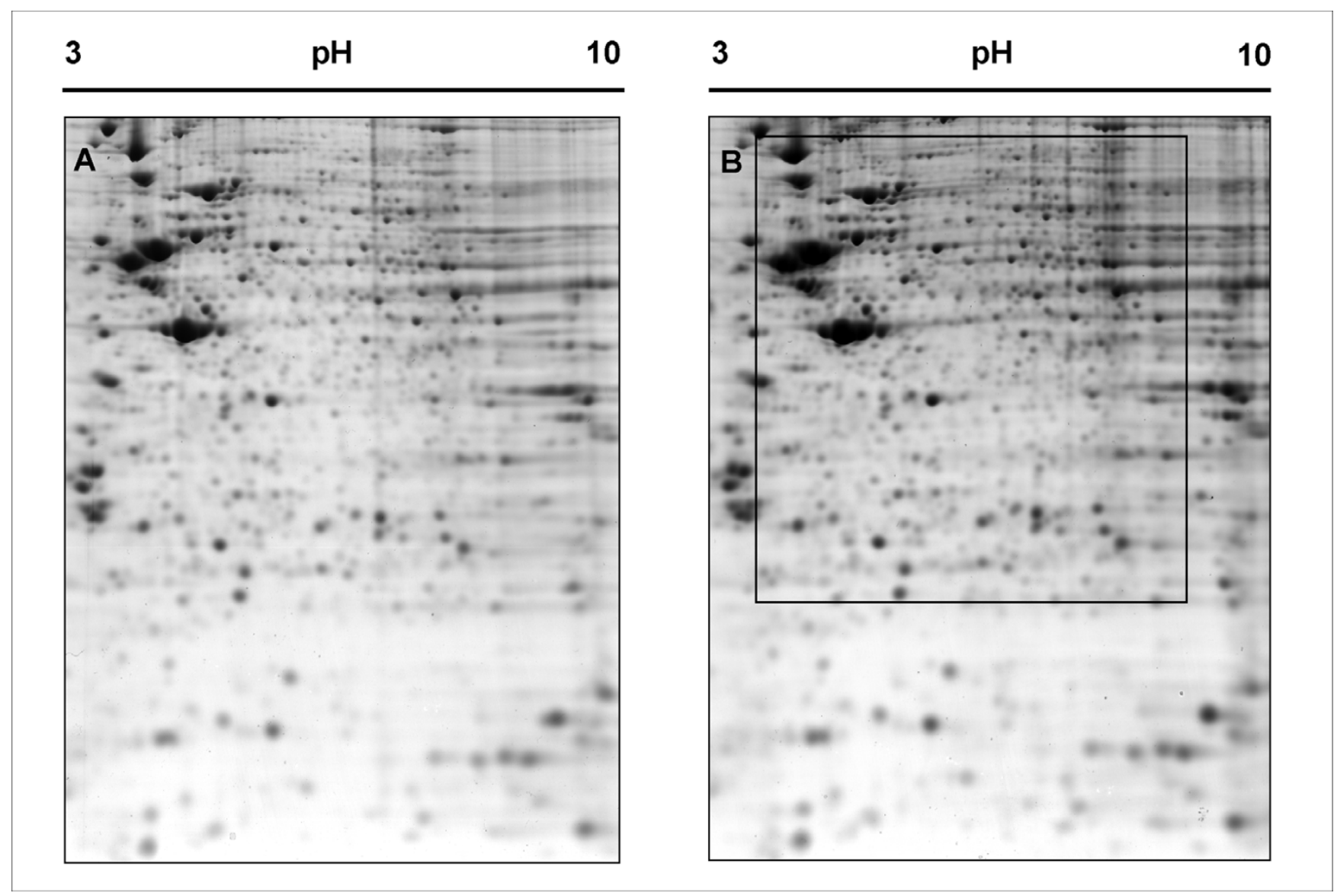

\section{Figure I}

2-DE pattern of untreated (A) and $6 \mathrm{~h}$ morphine-treated (B) SH-SY5Y cells. Sample were resolved by 2-DE on nonlinear $\mathrm{pH}$ 3-IO IPG strips followed by separation on a I2\% SDS-PAGE gel in the second dimension. Proteins were visualized by colloidal coomassie staining. The box in IB delineates the close-up presented on figure 2.

thase subunit $\mathrm{B}$ and bifunctional purine biosynthesis protein were upregulated at 6 and $24 \mathrm{~h}$. Rab7 was downregulated at 6 and $24 \mathrm{~h}$ while guanine nucleotide binding protein $\beta$ subunit 2-like 1 (also known as RACK1) was downregulated at 6 and $72 \mathrm{~h}$. Adenylosuccinate synthetase 2 was upregulated at $6 \mathrm{~h}$ and downregulated at 72 h. Septin 11 and spot 24 containing a mixture of Rab GDI $\beta$ and mitochondrial-processing peptidase $\beta$ were upregulated at $6 \mathrm{~h}$, returned to baseline at $24 \mathrm{~h}$ and showed only a minor upregulation at $72 \mathrm{~h}$. Finally, only malate dehydrogenase was downregulated at each time point.

\section{Discussion}

Overall, the present whole cell proteomic analysis has identified 53 proteins from 55 spots whose relative volume is modified upon morphine treatment in SH-SY5Y cells. Once mixtures are excluded, 45 morphine-responsive proteins can be classified according to cellular function (see Additional file 1). These are involved in cell metabolism, organization of the cytoskeleton, vesicle traf- ficking, transcriptional regulation, protein translation, folding and degradation, and cell signaling.

The pattern of morphine-responsive proteins appears to be dependent on the duration of morphine treatment (compare Tables 1, 2 and 3), indicating that cellular adaptation to chronic morphine is a dynamic process. Such dynamic adaptation has previously been documented in the striatum of chronically morphine-treated rats, wherein various members of the Fos family of transcription factors are sequentially upregulated, implying that distinct sets of genes are regulated over time [3]. Alternatively, it is possible that changes could have been missed at some time point due to technical limitation. For example, RACK1 was found to be downregulated at each time point but this downregulation reached statistical significance only for the 6 and $72 \mathrm{~h}$ time points. The difficulty to detect subtle variations in low abundance proteins is a well known limitation of large scale proteomic studies. Thus, the present whole cell analysis failed to detect 
Table I: Proteins whose abundance in SH-SY5Y cells is regulated after $6 \mathrm{~h}$ of morphine treatment

\begin{tabular}{|c|c|c|c|c|c|c|c|}
\hline Spot \# & Protein & Accession \# (a) & MW (Da) & $\begin{array}{l}\text { Variation (\% of } \\
\text { control) (b) }\end{array}$ & MALDI peptides & $\%$ coverage & MS/MS peptides (c) \\
\hline 2 & Elongation factor G I & Q96RP9 & 83506 & $42 \pm 11$ & 13 & 16 & \\
\hline 3 & Ezrin & PI53II & 69268 & $165 \pm 26$ & 10 & 15 & \\
\hline 5 & Lamin $A / C$ & $\overline{P 02545}$ & 74139 & $203 \pm 21$ & 18 & 32 & \\
\hline 9 & Bifunctional purine biosynthesis protein & P31939 & 65088 & $122 \pm 16$ & 14 & 30 & \\
\hline 11 & no identification & & & $52 \pm 10$ & & & \\
\hline 14 & $\begin{array}{l}\text { Vacuolar ATP synthase subunit B, brain } \\
\text { isoform }\end{array}$ & $\underline{\mathrm{P} 21281}$ & 56501 & $151 \pm 17$ & 18 & 54 & \\
\hline 15 & Rho-GTPase-activating protein I & Q07960 & 50461 & $166 \pm 44$ & & & 4 \\
\hline 17 & Septin-1I & $\overline{\text { O9NVA2 }}$ & 49267 & $|4| \pm 19$ & 13 & 37 & \\
\hline 18 & ATP synthase beta chain & P06576 & 56560 & $35 \pm 9$ & 10 & 48 & \\
\hline 24 & $\begin{array}{l}\text { Rab GDP dissociation inhibitor beta } \\
\text { Mitochondrial-processing peptidase beta } \\
\text { subunit }\end{array}$ & $\frac{\mathrm{P} 50395}{075439}$ & $\begin{array}{l}50663 \\
55072\end{array}$ & $136 \pm 16$ & $\begin{array}{l}14 \\
12\end{array}$ & $\begin{array}{l}36 \\
25\end{array}$ & \\
\hline 27 & $\begin{array}{l}\text { Synaptic vesicle membrane protein VAT-I } \\
\text { homolog }\end{array}$ & Q99536 & 41920 & $141 \pm 17$ & 7 & 31 & \\
\hline 28 & Adenylosuccinate synthetase 2 & P30520 & 50097 & $147 \pm 14$ & & & 5 \\
\hline 36 & 40 kDa peptidyl-prolyl cis-trans isomerase & 008752 & 40632 & $174 \pm 42$ & 12 & 26 & \\
\hline 44 & Malate dehydrogenase, cytoplasmic & $\mathrm{P} 40925$ & 36295 & $50 \pm 9$ & 11 & 32 & \\
\hline 49 & $\begin{array}{l}\text { Guanine nucleotide binding protein beta } \\
\text { subunit 2-like I }\end{array}$ & $\underline{P 63244}$ & 35077 & $75 \pm 15$ & 15 & 69 & \\
\hline 52 & $\begin{array}{l}\text { Platelet-activating factor acetylhydrolase IB } \\
\text { gamma }\end{array}$ & Q15102 & 25734 & $70 \pm 14$ & & & 5 \\
\hline 53 & Triosephosphate isomerase & $\underline{P} 60174$ & 26538 & $186 \pm 60$ & 13 & 65 & \\
\hline 54 & Ras-related protein Rab-7 & $\overline{P 51149}$ & 23490 & $56 \pm 13$ & 13 & 65 & \\
\hline
\end{tabular}

aSwiss-Prot primary accession number

bMean \pm S.D., control refers to untreated cells.

cOnly peptides with a statistically significant Mascot score $(p<0.05)$ were considered

changes in heterotrimeric $G$ protein $\beta$ subunits and prohibitin whose relative abundance was previously shown to be decreased in the detergent-resistant membrane (DRM) raft fraction isolated from morphine-treated cells [11]. This is readily explained by the fact that standard sample preparation for 2-DE (the present study), which involves incubation with Triton X-100 at $4{ }^{\circ} \mathrm{C}$ followed by high speed centrifugation, has eliminated the DRM raft fraction and the proteins which this fraction is enriched in, including heterotrimeric $G$ protein subunits [11]. In addition, the present study has focused onto the $\sim 950$ most abundant and soluble proteins of the cell, which represent only 1 to $10 \%$ of the total protein species likely to be expressed in a cell. This illustrates the necessity of combining both whole cell and sub-proteome targeted analyses to obtain a clear picture of the proteome of a given cell type.

Four recently published proteomic analyzes have addressed chronic morphine effects in the brain [12-15]. Seven of our morphine-responsive proteins, or closely related isoforms, were also found to be modified in these studies: ATP synthase beta chain, vacuolar ATP synthase subunit $\mathrm{B}$, malate dehydrogenase, triosephosphate isomerase, rab GDP dissociation inhibitor beta, peptidylprolyl isomerase, and septin- 11 . These are indications that at least some of the brain protein changes associated with chronic morphine treatment in vivo can be reproduced in our cellular model in vitro after a relatively short time of morphine exposure. Conversely, some of the new changes identified in our present in vitro study may provide hints as to what neuronal processes may be regulated upon chronic morphine treatment in vivo.

Ascribing a precise role for the identified proteins in mediating specific chronic morphine effects in neurons would be too speculative at this stage. However it appears noteworthy to highlight possible links between selected proteins identified in this study and known effects of chronic morphine. Similar to what was recently described for cocaine [16], some of morphine transcriptional effects could be mediated at the level of histone acetylation and chromatin remodeling since two histone acetyltransferase subunits (RuvB-like 1 and histone acetyltransferase type B subunit 2) are upregulated after $24 \mathrm{~h}$ of treatment. The variation in $20 \mathrm{~S}$ proteasome subunit composition observed after $72 \mathrm{~h}$ of morphine is consistent with previous studies demonstrating a role for the ubiquitin/proteasome pathway in mediating chronic morphine effects $[11,17]$.

Such transcriptional and post-translational regulations can lead to numerous changes in cellular function among which alterations in cellular architecture $[18,19]$, vesicle trafficking [4] and signal transduction pathways are essential for drug-induced neuronal plasticity. Regarding neuronal architecture and synaptic remodelling, potentially interesting morphine targets are ERM proteins, septins 


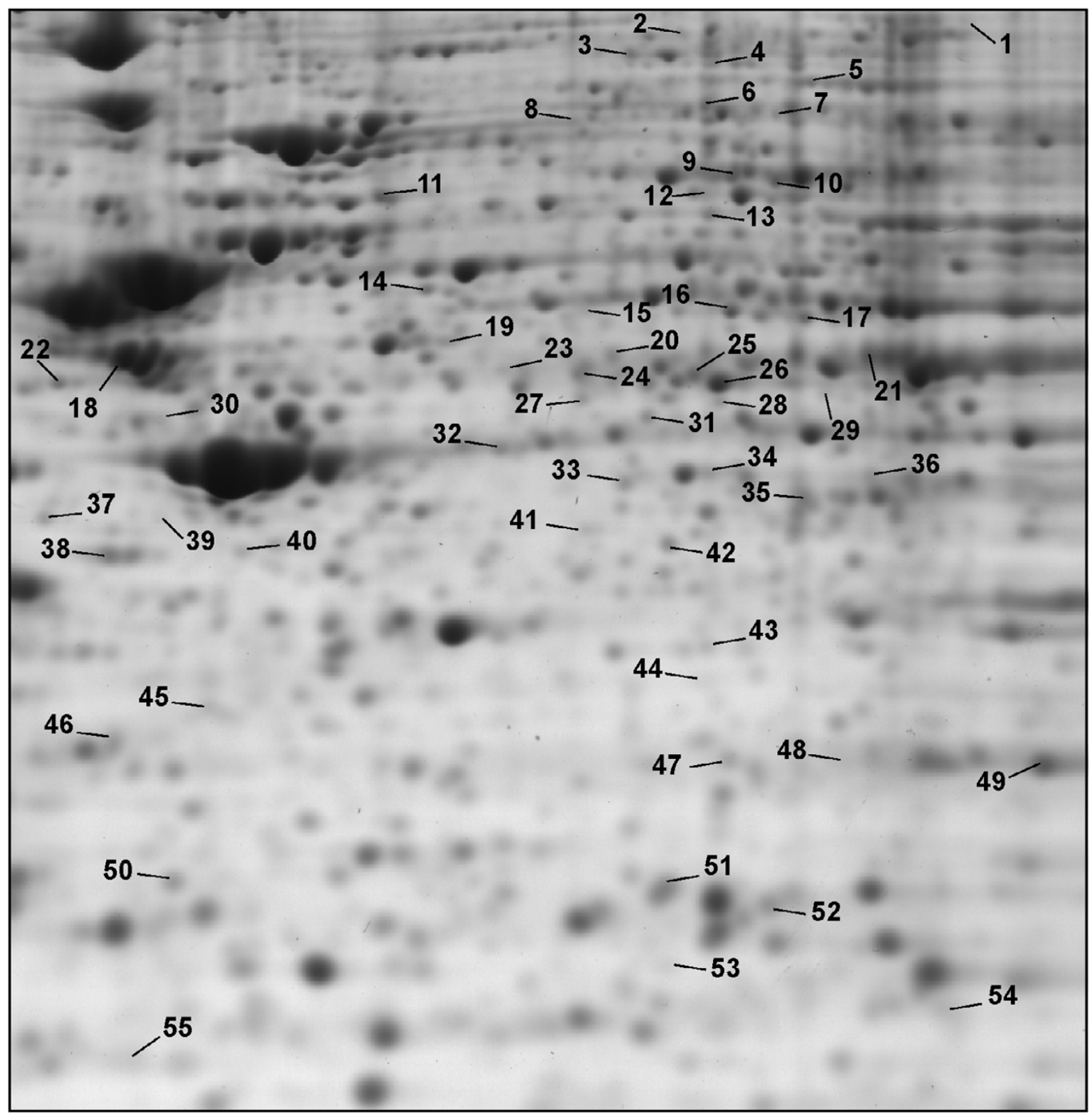

Figure 2

Close-up from a representative 2-D gel showing the spots whose abundance in SH-SY5Y cells is regulated after chronic morphine treatment. Spots numbers refer to numbers on Tables I, 2 and 3 where quantitative analysis and mass spectrometric data are presented.

[20] and Rho-GTPase-activating protein 1 [21]. Concerning vesicular transport, the SNAP-alpha downregulation observed in our study is consistent with the recent observation that chronic morphine could induce an inhibition of SNARE complex formation [22]. Morphine could also act at the level of small GTPases of the rab family which are essential for vesicle trafficking. The observed increase in rab GDP dissociation inhibitor beta after $72 \mathrm{~h}$ of morphine could result in an alteration of the amount of active rab proteins available for neurotransmitter release [23]. These data are all consistent with chronic morphine modifying neurotransmitter secretion and synapse efficacy. 
Table 2: Proteins whose abundance in SH-SY5Y cells is regulated after $24 \mathrm{~h}$ of morphine treatment

\begin{tabular}{|c|c|c|c|c|c|c|c|}
\hline Spot \# & Protein & Accession \# (a) & MW (Da) & $\begin{array}{l}\text { Variation }(\% \text { of } \\
\text { control) }(b)\end{array}$ & MALDI peptides & $\%$ coverage & MS/MS peptides (c) \\
\hline 1 & ATP-dependent RNA helicase DDXI & Q92499 & 82432 & $54 \pm 10$ & 27 & 32 & \\
\hline 7 & $\begin{array}{l}\text { Glycerol-3-phosphate dehydrogenase, } \\
\text { mitochondrial }\end{array}$ & $\underline{\mathrm{P} 43304}$ & 80815 & $75 \pm 7$ & 15 & 22 & \\
\hline 9 & Bifunctional purine biosynthesis protein & P31939 & 65088 & $118 \pm 11$ & 14 & 30 & \\
\hline 14 & $\begin{array}{l}\text { Vacuolar ATP synthase subunit B, brain } \\
\text { isoform }\end{array}$ & $\underline{P 21281}$ & 56501 & $13 \mid \pm 13$ & 18 & 54 & \\
\hline 16 & RuvB-like I & Q9Y265 & 50228 & $144 \pm 32$ & 16 & 66 & \\
\hline 19 & $\begin{array}{l}\text { 4-trimethylaminobutyraldehyde } \\
\text { dehydrogenase } \\
\text { WD-repeat protein } 12\end{array}$ & $\frac{\text { P49189 }}{\text { Q9GZL7 }}$ & $\begin{array}{l}53802 \\
48190\end{array}$ & $145 \pm 24$ & $\begin{array}{l}15 \\
12\end{array}$ & $\begin{array}{l}32 \\
25\end{array}$ & \\
\hline 20 & Alpha-enolase & P06733 & 47038 & $45 \pm 15$ & 18 & 60 & \\
\hline 21 & Alpha-enolase & P06733 & 47038 & $184 \pm 53$ & & & 6 \\
\hline 22 & Histone acetyltransferase type B subunit 2 & $\underline{016576}$ & 47820 & $145 \pm 65$ & 10 & 30 & \\
\hline 30 & $\begin{array}{l}\text { Heterogeneous nuclear riboprotein } \mathrm{F} \\
\text { Eucaryotic translation initiation factor } 3 \\
\text { subunit } 5\end{array}$ & $\underline{000303}$ & $\begin{array}{l}45853 \\
37654\end{array}$ & $|8| \pm 60$ & $\begin{array}{l}12 \\
7\end{array}$ & $\begin{array}{l}42 \\
32\end{array}$ & \\
\hline 32 & Beta-succinyl CoA synthetase & $\underline{07 Z 503}$ & 43611 & $74 \pm 10$ & 15 & 35 & \\
\hline 33 & Galactokinase & $\underline{P 51570}$ & 42272 & $58 \pm 9$ & 15 & 43 & \\
\hline 35 & Acyl-CoA hydrolase & 000154 & 41796 & $166 \pm 33$ & II & 44 & \\
\hline 37 & Arsenical pump-driving ATPase & $\underline{043681}$ & 38793 & $167 \pm 29$ & 8 & 26 & \\
\hline 38 & $\begin{array}{l}\text { Serine-threonine kinase receptor } \\
\text { associated protein }\end{array}$ & Q9Y3F4 & 38756 & $164 \pm 31$ & 14 & 48 & \\
\hline 41 & $\begin{array}{l}\text { Protein phosphatase } 2 \mathrm{~A} \text {, regulatory subunit } \\
\mathrm{B}^{\prime} \\
\text { Calponin-3 }\end{array}$ & $\begin{array}{l}\text { Q15257 } \\
\text { Q15417 }\end{array}$ & $\begin{array}{l}40682 \\
36561\end{array}$ & $65 \pm 8$ & $\begin{array}{l}10 \\
7\end{array}$ & $\begin{array}{l}30 \\
30\end{array}$ & \\
\hline 42 & Biliverdin reductase $A$ & P53004 & 33428 & $84 \pm 6$ & 12 & 44 & \\
\hline 44 & Malate dehydrogenase, cytoplasmic & P40925 & 36295 & $49 \pm 25$ & 11 & 32 & \\
\hline 46 & Annexin A5 & $\underline{\mathrm{P} 08758}$ & 35806 & $|52 \pm 4|$ & 18 & 70 & \\
\hline 51 & Endoplasmic reticulum protein ERp29 & P30040 & 28993 & $76 \pm 14$ & 8 & 46 & \\
\hline 54 & Ras-related protein Rab-7 & $P 51149$ & 23490 & $58 \pm 12$ & 13 & 65 & \\
\hline
\end{tabular}

aSwiss-Prot primary accession number

bMean \pm S.D., control refers to untreated cells.

cOnly peptides with a statistically significant Mascot score $(p<0.05)$ were considered

Finally, chronic morphine induced a change in abundance of several signaling proteins: heterotrimeric $\mathrm{G}$ protein subunit $\alpha$ i2, serine-threonine kinase receptor associated protein and receptor for activated $\mathrm{C}$ kinase 1 (RACK1). The downregulation of G $\alpha$ i2 has already been described in our previous study [11] and will not be discussed further. The observed upregulation of serine-threonine kinase receptor associated protein provides a new link between morphine signaling and the phosphatidylinositol 3-kinase/Akt pathway [24]. RACK1 downregulation in brains of morphine-treated rats has been described previously but it has only been discussed in terms of changes in PKC activity since it was its only known function at this time [25]. Since then, RACK1 has been characterized as a scaffolding protein for many proteins involved in cell signaling [26]. Alterations in RACK1 abundance could thus coordinate changes in distinct signaling pathways and its role in molecular adaptations to drugs of abuse deserves further investigation [27].

\section{Conclusion}

In conclusion, our differential proteomics study has identified several candidate proteins that could be implicated in the molecular adaptation of neurons to chronic morphine treatment. In particular, changes in vesicular traf- ficking and proteasome-dependent protein degradation are known to be critical for various forms of synaptic plasticity such as long term potentiation or depression $[28,29]$. These adaptations as well as their role in the development of drug dependence have now to be validated in animal models of addiction.

\section{Methods}

\section{Cell culture and treatment}

Human SH-SY5Y neuroblastoma cells were transfected with N-terminal T7-tagged human MOP receptor in pRCCMV using lipofectamine [11]. Stably transfected G418resistant cells were grown in high glucose DMEM (Gibco BRL) containing $10 \%$ fetal calf serum, $50 \mu \mathrm{g} / \mathrm{ml}$ gentamicine (Gibco BRL), and $400 \mu \mathrm{g} / \mathrm{ml} \mathrm{G418} \mathrm{(Gibco} \mathrm{BRL),} \mathrm{in}$ $5 \% \mathrm{CO}_{2}$ at $37^{\circ} \mathrm{C}$. Cells in $14 \mathrm{~cm}$ dishes were treated by diluting morphine sulphate directly in the culture medium. The cell density was adjusted so that the cultures were nearly confluent at the end of each treatment. For 72 $\mathrm{h}$ treatment, medium was changed and fresh morphine was added every day. Four independent experiments were performed for each treatment time. 
Table 3: Proteins whose abundance in SH-SY5Y cells is regulated after $72 \mathrm{~h}$ of morphine treatment

\begin{tabular}{|c|c|c|c|c|c|c|c|}
\hline Spot \# & Protein & Accession \# (a) & MW (Da) & $\begin{array}{l}\text { Variation }(\% \text { of } \\
\text { control) (b) }\end{array}$ & MALDI peptides & $\%$ coverage & $\begin{array}{l}\text { MS/MS peptides } \\
\text { (c) }\end{array}$ \\
\hline 4 & Radixin & P3524I & 68564 & $50 \pm 17$ & & & 4 \\
\hline 6 & no identification & & & $48 \pm 23$ & & & \\
\hline 8 & Heat shock cognate 7I kDa protein & $\mathrm{PII} 142$ & 70898 & $172 \pm 48$ & 11 & 23 & \\
\hline 10 & Lamin $A / C$ & $\overline{\mathrm{P} 02545}$ & 74139 & $78 \pm 15$ & 22 & 30 & \\
\hline 12 & T-complex protein I, zeta subunit & P40227 & 57893 & $57 \pm 17$ & 15 & 29 & \\
\hline 13 & $\begin{array}{l}\text { Dihydropyrimidinase-related } \\
\text { protein } 3\end{array}$ & $\mathrm{Q} 14195$ & 61963 & $57 \pm 21$ & 13 & 40 & \\
\hline 17 & Septin-II & Q9NVA2 & 49267 & $110 \pm 3$ & 13 & 37 & \\
\hline 23 & Rab GDP dissociation inhibitor beta & P50395 & 50663 & $|79 \pm 6|$ & II & 34 & \\
\hline 24 & $\begin{array}{l}\text { Rab GDP dissociation inhibitor beta } \\
\text { Mitochondrial-processing peptidase } \\
\text { beta subunit }\end{array}$ & $\underline{\mathrm{P} 50395}$ & $\begin{array}{l}50663 \\
55072\end{array}$ & $114 \pm 6$ & $\begin{array}{l}14 \\
12\end{array}$ & $\begin{array}{l}36 \\
25\end{array}$ & \\
\hline 25 & Proliferation-associated protein 2G4 & Q9U080 & 43787 & $54 \pm 20$ & 15 & 44 & \\
\hline 26 & Elongation factor I-gamma & P26641 & 49988 & $89 \pm 5$ & 16 & 36 & \\
\hline 28 & Adenylosuccinate synthetase 2 & P30520 & 50097 & $73 \pm 16$ & & & 5 \\
\hline 29 & $\begin{array}{l}\text { Elongation factor I-gamma } \\
\text { tRNA-nucleotidyltransferase I }\end{array}$ & $\underline{\mathrm{P} 26641}$ & $\begin{array}{l}49988 \\
50340\end{array}$ & $51 \pm 27$ & $\begin{array}{c}11 \\
9\end{array}$ & $\begin{array}{l}24 \\
19\end{array}$ & \\
\hline 31 & Ornithine aminotransferase. & P04I8I & 48535 & $84 \pm 3$ & 14 & 37 & \\
\hline 34 & Septin-2 & $\overline{Q 15019}$ & 41487 & $72 \pm 15$ & 12 & 36 & \\
\hline 39 & $\begin{array}{l}\text { Ubiquitin-like I activating enzyme } \\
\text { EIA }\end{array}$ & Q9UBE0 & 38450 & $45 \pm 14$ & 11 & 35 & \\
\hline 40 & $\begin{array}{l}\text { Guanine nucleotide binding protein, } \\
\text { alpha inhibiting activity polypeptide } 2\end{array}$ & Q96C71 & 40493 & $65 \pm 8$ & 9 & 37 & \\
\hline 43 & $\begin{array}{l}\text { 3-mercaptopyruvate } \\
\text { sulfurtransferase }\end{array}$ & $\underline{\mathrm{P} 25325}$ & 33047 & $69 \pm 9$ & & & 6 \\
\hline 44 & Malate dehydrogenase, cytoplasmic & P40925 & 36295 & $73 \pm 16$ & 11 & 32 & \\
\hline 45 & $\begin{array}{l}\text { Alpha-soluble NSF attachment } \\
\text { protein }\end{array}$ & P54920 & 33247 & $45 \pm 12$ & 8 & 45 & \\
\hline 47 & Nuclear protein Hcc-I & $\underline{P 82979}$ & 23540 & $77 \pm 9$ & 9 & 41 & \\
\hline 48 & no identification & & & $49 \pm 32$ & & & \\
\hline 49 & $\begin{array}{l}\text { Guanine nucleotide binding protein } \\
\text { beta subunit } 2 \text {-like I }\end{array}$ & $\underline{P 63244}$ & 35077 & $74 \pm 9$ & 15 & 69 & \\
\hline 50 & Proteasome subunit alpha type 3 & $\underline{\mathrm{P} 25788}$ & 28302 & $73 \pm 13$ & 8 & 46 & \\
\hline 55 & Proteasome subunit beta type 6 & $\overline{\mathrm{P} 28072}$ & 25358 & $143 \pm 11$ & 7 & 23 & \\
\hline
\end{tabular}

aSwiss-Prot primary accession number

bMean \pm S.D., control refers to untreated cells.

cOnly peptides with a statistically significant Mascot score $(p<0.05)$ were considered

\section{Sample preparation for 2-DE}

Following treatment, the culture medium was removed and the cells were scraped into PBS and centrifuged at $1000 \times \mathrm{g}$ for $10 \mathrm{~min}$ at $4^{\circ} \mathrm{C}$. The supernatant was discarded and the pellet was frozen and stored at $-80^{\circ} \mathrm{C}$ for 2 hours. Cells were then resuspended in $500 \mu \mathrm{l}$ of lysis buffer [50 mM Tris- $\mathrm{HCl} \mathrm{pH} 7.4,150 \mathrm{mM} \mathrm{NaCl}, 10 \mathrm{mM}$ EDTA, proteinase inhibitors (Complete Mini tablets, Roche) and 1\% (v:v) Triton X-100 (Sigma)], and protein extraction allowed to proceed for $3 \mathrm{~h}$ at $4^{\circ} \mathrm{C}$. The extract was centrifuged at $20,000 \times \mathrm{g}$ for $20 \mathrm{~min}$ at $4^{\circ} \mathrm{C}$ in order to remove cell debris and insoluble material. The supernatant was delipidated and desalted using methanol/chloroform precipitation by mixing with $2 \mathrm{ml}$ of methanol, 500 $\mu \mathrm{l}$ of chloroform and $1.5 \mathrm{ml}$ of water, and centrifuging at $20,000 \times \mathrm{g}$ for $5 \mathrm{~min}$, at room temperature. The pellet was washed with $1.5 \mathrm{ml}$ of methanol and vacuum-dried. Proteins were then resuspended in $400 \mu$ l of 2-DE buffer (Cellular and Organelle Membrane Solubilizing Reagent, Sigma), reduced for $1 \mathrm{~h}$ at room temperature by adding tributylphosphine to a final concentration of $5 \mathrm{mM}$, and alkylated in the dark for $1.5 \mathrm{~h}$ at room temperature by adding iodoacetamide to a final concentration of $15 \mathrm{mM}$. Protein concentration was determined by using the Bradford assay (Biorad).

\section{Two-dimensional gel electrophoresis}

The reduced and alkylated protein samples $(300 \mu \mathrm{g})$ were used to rehydrate $13 \mathrm{~cm} \mathrm{pH} \mathrm{3-10} \mathrm{NL} \mathrm{Immobilized} \mathrm{pH}$ Gradient (IPG) strips (Amersham Biosciences). $1.2 \mu \mathrm{l}$ of IPG buffer pH 3-10 NL (Amersham Biosciences) and $2 \mu \mathrm{l}$ of $1 \%(\mathrm{w}: \mathrm{v})$ orange $\mathrm{G}$ were added to $250 \mu \mathrm{l}$ of sample before application to the strip. Strips were focused on the IPGphor IEF (isoelectrofocusing) Cell (Amersham Biosciences) for $80000 \mathrm{Vh}$. After $6 \mathrm{~h}$ of passive rehydration and $6 \mathrm{~h}$ of active rehydration $(30 \mathrm{~V})$, the voltage was set to $300 \mathrm{~V}$ for $4 \mathrm{~h}$. It was then increased from 300 to $8000 \mathrm{~V}$ during $8 \mathrm{~h}$, followed by additional hours at $8000 \mathrm{~V}$ (until the desired volt $\times$ hour product is reached). Focused IPG strips were equilibrated in SDS-equilibration buffer containing $6 \mathrm{M}$ urea, 2\% (w:v) SDS, $50 \mathrm{mM}$ Tris-HCl $(\mathrm{pH}$ $8.8), 30 \%(\mathrm{v}: \mathrm{v})$ glycerol and $0.01 \%(\mathrm{w} / \mathrm{v})$ bromophenol blue as a tracking dye for $2 \times 10 \mathrm{~min}$. The equilibrated strips were loaded onto $16 \times 16 \mathrm{~cm}, 1 \mathrm{~mm}$ thick, $12 \%$ 
polyacrylamide SDS gels. Runs were performed at $10 \mathrm{~mA} /$ gel (SE600 Ruby, Amersham Biosciences) until the bromophenol blue reached the bottom of the gel. Gels were then stained overnight using Coomassie colloidal blue ( $1 \mathrm{~g} / \mathrm{l}$, Sigma) and destained for $1 \mathrm{~h}$ in $1 \%(\mathrm{v} / \mathrm{v})$ acetic acid solution.

\section{Image analysis}

Gels were scanned using a GS-800 Calibrated Densitometer (Biorad) and analyzed using ImageMaster Platinum software (Amersham Biosciences). Spots were detected on quadruplicate gels and manually edited. Normalization was performed by dividing the volume $(\mathrm{OD} \times$ surface $)$ of each spot by the total volume of every spot on the gel to give a \%volume value. Gels were then matched and each group of equivalent spots was compared. In a preliminary experiment, 4 independent control gel were compared. Pair-wise comparison of spot \%volumes gave linear regressions of the type $\mathrm{y}=\mathrm{ax}+\mathrm{b}$ where $\mathrm{a}=1.03 \pm 0.06$ and $\mathrm{b}=-0.0019 \pm 0.0034$, and a correlation coefficient of 0.95 \pm 0.011 . Average coefficient of variation $(\mathrm{SD} /$ mean $\times 100)$ for all spot \%volumes was $19.8 \pm 10.1$. This level of reproducibility is indicative of a statistical power of 80 to $90 \%$ for a sample size of 4 and a 0.05 p-value [30]. Having assessed the reliability of our analyses, \%volumes of spots from control gels were compared to those of spots from treated gels using a Student unpaired t test. Groups of spots showing a statistically significant difference in relative volume $(\mathrm{p}<0.05, \mathrm{df}=6)$ between control and morphine-treated samples were first visually controlled in order to make sure that \%volume changes were not due to spot detection or matching errors. Confirmed spots were then selected for identification by mass spectrometry.

\section{In-gel protein digestion}

Spots of interest were manually excised from a representative gel. The gel pieces were washed with water and destained first in $160 \mu \mathrm{l}$ of $50 \%$ (v:v) acetronitrile (ACN) in water then in $160 \mu \mathrm{l}$ of $50 \%$ (v:v) ACN in $0.1 \mathrm{M}$ $\mathrm{NH}_{4} \mathrm{HCO}_{3}$, dehydrated with $80 \mu \mathrm{l} \mathrm{ACN}$ and dried in a vacuum centrifuge. Gel pieces were rehydrated in a sufficient covering volume of modified trypsin solution $(12.5 \mathrm{ng} / \mu \mathrm{l}$ in $12.5 \mathrm{mM} \mathrm{NH}_{4} \mathrm{HCO}_{3}$; Promega) and incubated overnight at $37^{\circ} \mathrm{C}$. Prior to peptide extraction, $0.5 \mu \mathrm{l}$ of the tryptic digest was spotted onto the MALDI target plate. Peptides were extracted two times at $37^{\circ} \mathrm{C}$ for 30 min with shaking, first using $50 \% 25 \mathrm{mM} \mathrm{NH}_{4} \mathrm{HCO}_{3} / 50 \% \mathrm{ACN}$ and then $5 \%$ formic acid/50\% ACN in water. The peptide mixture was concentrated in a vacuum centrifuge to a final volume of about $10 \mu \mathrm{l}$.

\section{MALDI-TOF MS analysis}

MALDI-TOF MS analyses were performed on a MALDITOF/TOF instrument (4700 Proteomics Analyzer; Applied Biosystems, Foster City, CA). $0.5 \mu$ l of tryptic digest super- natant was loaded onto the MALDI target plate and air dried. $0.3 \mu \mathrm{l}$ of matrix solution ( $\alpha$-cyano-4-hydroxycinnamic acid; $5 \mathrm{mg} / \mathrm{ml}$ in $\mathrm{H}_{2} \mathrm{O}$ /acetonitrile/TFA, 50:50:0.1) was then added. Mass spectra were acquired in an automated positive reflector mode from $\mathrm{m} / z 700$ to $\mathrm{m} / \mathrm{z} 3500$. Trypsin autolytic peptides ( $\mathrm{m} / z 842.51$ and 2211.10$)$ were used to internally calibrate each spectrum to a mass accuracy within $30 \mathrm{ppm}$. Spectra were analyzed using GPS Explorer (version 3.5, Applied Biosystems) which acts as an interface between the Oracle database containing raw spectra and a local copy of the Mascot search engine (version 2.0 ; Matrix Science, London, U.K.). Peptide peaks with a signal/noise ratio greater than 10 were searched against human sequences in the Swiss-Prot database (Release 48 from September $2005 ; 194317$ entries). No missed cleavage was allowed and the data were searched using carbamidomethylation of cysteine as fixed modification whereas oxidation of methionine and N-acetylation of the proteins were considered as variable modifications. A protein was considered correctly identified if the Protein Score Confidence Interval calculated by the GPS Explorer Results Browser was greater than 99\% (see Additional file 2).

\section{NanoLC-ESI-Q-TOF MSIMS analysis}

When MALDI-TOF data were not conclusive (protein score not significant), protein identification was confirmed by MS/MS analyses. Tryptic peptide extracts were subjected to nanoLC-MS/MS analysis on an ESI-Q-TOF mass spectrometer (QSTAR XL, Applied Biosystems) operating in positive mode with a $2.1 \mathrm{kV}$ spray voltage. Chromatographic separation was performed onto a $75 \mu \mathrm{m}$ ID $\times 15 \mathrm{~cm}$ PepMap C18 column (Dionex/LC Packings, USA) at a flow rate of $200 \mathrm{~nL} /$ minute using a linear gradient of increasing $\mathrm{ACN}$ in water (5-50\%) over 40 min with $0.1 \%$ formic acid as ion pairing agent. Data were acquired with Analyst QS (version 1.1, Applied Biosystems). MS spectra were acquired for one second. For each MS spectrum, the two most intense multiple charged peaks were selected for generation of subsequent Collision Induced Dissociation (CID) mass spectra. The collision energy was automatically adjusted based upon peptide charge and mass to charge $(\mathrm{m} / \mathrm{z})$ ratio. A dynamic exclusion window was applied to prevent repetitive selection of the same ions within $30 \mathrm{sec}$. Data were analyzed using Analyst QS software (version 1.1) and MS/MS centroid peak lists were generated using the Mascot.dll script (version 1.6b13). MS/MS centroid peaks were thresholded at $0 \%$ of the base peak. Data were searched against human sequences in the Swiss-Prot/TrEMBL database as of October 2005 using Mascot (version 2.0). Peptide tolerance in MS and MS/MS modes was $0.5 \mathrm{Da}$. Trypsin was designated as the protease, and up to two missed cleavages were allowed. Carbamidomethylation of cysteine was searched as fixed modification, while oxidation of methionine and amino-terminal 
protein acetylation were allowed as variable modifications. Identification was considered positive if the protein was identified on the bases of at least two peptides with a score greater then the significance threshold score determined by the Mascot Search program (>36) (see Additional file 2).

\section{Competing interests}

The author(s) declare that they have no competing interests.

\section{Authors' contributions}

All authors read and approved the final manuscript.

JN carried out the proteomic studies, data analysis, and participated in drafting the manuscript.

SU carried out the mass spectrometric studies and helped to draft the manuscript.

KC participated in experiment and data analysis.

BM supervised mass spectrometric experiments.

JCM participated in the design of the study and in drafting the manuscript.

LM designed the study, supervised experiments and data analysis, and drafted the manuscript.

\section{Additional material}

\section{Additional file 1}

Functional classification of proteins regulated by chronic morphine. Click here for file

[http://www.biomedcentral.com/content/supplementary/14775956-4-23-S1.pdf]

\section{Additional file 2}

Complete mass spectrometry data for identification.

Click here for file

[http://www.biomedcentral.com/content/supplementary/14775956-4-23-S2.pdf]

\section{Acknowledgements}

This work was supported by CNRS ("Protéomique et Génie des Protéines" programme grant PGP 03/057). Financial support from the Région MidiPyrénées and the Génopôle Toulouse/Midi-Pyrénées to BM is also gratefully acknowledged.

\section{References}

I. Koob GF, Le Moal M: Plasticity of reward neurocircuitry and the 'dark side' of drug addiction. Nat Neurosci 2005, 8: I442-I444.

2. Meunier JC: Opioid receptors, tolerance and dependence. Therapie 1992, 47:495-502.
3. Nestler Ej: Molecular basis of long-term plasticity underlying addiction. Nat Rev Neurosci 200I, 2: I 19-128.

4. Williams JT, Christie MJ, Manzoni O: Cellular and synaptic adaptations mediating opioid dependence. Physiol Rev 200I, $81: 299-343$

5. Rhodes JS, Crabbe JC: Gene expression induced by drugs of abuse. Curr Opin Pharmacol 2005, 5:26-33.

6. Ammon S, Mayer P, Riechert U, Tischmeyer H, Hollt V: Microarray analysis of genes expressed in the frontal cortex of rats chronically treated with morphine and after naloxone precipitated withdrawal. Brain Res Mol Brain Res 2003, I I 2: I I3-I 25.

7. McClung CA, Nestler EJ, Zachariou V: Regulation of gene expression by chronic morphine and morphine withdrawal in the locus ceruleus and ventral tegmental area. J Neurosci 2005, 25:6005-60I5.

8. Gygi SP, Rochon Y, Franza BR, Aebersold R: Correlation between protein and mRNA abundance in yeast. Mol Cell Biol 1999, 19:1720-1730.

9. Williams K, Wu T, Colangelo C, Nairn AC: Recent advances in neuroproteomics and potential application to studies of drug addiction. Neuropharmacology 2004, 47 Suppl I:I48-I66.

10. Kazmi SM, Mishra RK: Comparative pharmacological properties and functional coupling of mu and delta opioid receptor sites in human neuroblastoma SH-SY5Y cells. Mol Pharmacol 1987, 32:109-118.

II. Mouledous L, Neasta J, Uttenweiler-Joseph S, Stella A, Matondo M, Corbani M, Monsarrat B, Meunier JC: Long-term morphine treatment enhances proteasome-dependent degradation of $\mathbf{G}$ beta in human neuroblastoma SH-SY5Y cells: correlation with onset of adenylate cyclase sensitization. Mol Pharmacol 2005, 68:467-476.

12. Kim SY, Chudapongse N, Lee SM, Levin MC, Oh JT, Park HJ, Ho IK: Proteomic analysis of phosphotyrosyl proteins in morphinedependent rat brains. Brain Res Mol Brain Res 2005, I33:58-70.

13. Prokai L, Zharikova AD, Stevens SM Jr.: Effect of chronic morphine exposure on the synaptic plasma-membrane subproteome of rats: a quantitative protein profiling study based on isotope-coded affinity tags and liquid chromatography/mass spectrometry. J Mass Spectrom 2005, 40:169-175.

14. Li KW, Jimenez CR, van der Schors RC, Hornshaw MP, Schoffelmeer $A N$, Smit AB: Intermittent administration of morphine alters protein expression in rat nucleus accumbens. Proteomics 2006, 6:2003-2008

15. Bierczynska-Krzysik A, Bonar E, Drabik A, Noga M, Suder P, Dylag T, Dubin A, Kotlinska J, Silberring J: Rat brain proteome in morphine dependence. Neurochem Int 2006, 49:40I-406.

16. Kumar A, Choi KH, Renthal W, Tsankova NM, Theobald DE, Truong HT, Russo SJ, Laplant Q, Sasaki TS, Whistler KN, Neve RL, Self DW, Nestler EJ: Chromatin remodeling is a key mechanism underlying cocaine-induced plasticity in striatum. Neuron 2005, 48:303-3।4

17. Rambhia S, Mantione KJ, Stefano GB, Cadet P: Morphine modulation of the ubiquitin-proteasome complex is neuroprotective. Med Sci Monit 2005, I I:BR386-396.

18. Robinson TE, Gorny G, Savage VR, Kolb B: Widespread but regionally specific effects of experimenter- versus selfadministered morphine on dendritic spines in the nucleus accumbens, hippocampus, and neocortex of adult rats. Synapse 2002, 46:27I-279.

19. Liao D, Lin H, Law PY, Loh HH: Mu-opioid receptors modulate the stability of dendritic spines. Proc Natl Acad Sci U S A 2005, 102: $1725-1730$

20. Cheng L, Itoh K, Lemmon V: LI-mediated branching is regulated by two ezrin-radixin-moesin (ERM)-binding sites, the RSLE region and a novel juxtamembrane ERM-binding region. J Neurosci 2005, 25:395-403.

21. Threadgill R, Bobb K, Ghosh A: Regulation of dendritic growth and remodeling by Rho, Rac, and Cdc42. Neuron 1997, 19:625-634.

22. Xu NJ, Yu YX, Zhu JM, Liu H, Shen L, Zeng R, Zhang X, Pei G: Inhibition of SNAP-25 phosphorylation at Ser 187 is involved in chronic morphine-induced down-regulation of SNARE complex formation. J Biol Chem 2004, 279:4060I-40608.

23. Goody RS, Rak A, Alexandrov K: The structural and mechanistic basis for recycling of Rab proteins between membrane compartments. Cell Mol Life Sci 2005, 62:1657-1670. 
24. Seong HA, Jung $\mathrm{H}$, Choi HS, Kim KT, Ha H: Regulation of transforming growth factor-beta signaling and PDKI kinase activity by physical interaction between PDKI and serinethreonine kinase receptor-associated protein. J Biol Chem 2005, 280:42897-42908.

25. Escriba PV, Garcia-Sevilla JA: Parallel modulation of receptor for activated $C$ kinase $I$ and protein kinase $C$-alpha and beta isoforms in brains of morphine-treated rats. BrJ Pharmacol 1999 , 1 27:343-348.

26. McCahill A, Warwicker J, Bolger GB, Houslay MD, Yarwood SJ: The RACKI scaffold protein: a dynamic cog in cell response mechanisms. Mol Pharmacol 2002, 62:126|-1273.

27. Ron D, Jurd R: The "ups and downs" of signaling cascades in addiction. SCi STKE 2005, 2005:rel4.

28. Kennedy MJ, Ehlers MD: Organelles and trafficking machinery for postsynaptic plasticity. Annu Rev Neurosci 2006, 29:325-362.

29. Ehlers MD: Activity level controls postsynaptic composition and signaling via the ubiquitin-proteasome system. Nat Neurosci 2003, 6:23I-242.

30. Molloy MP, Brzezinski EE, Hang J, McDowell MT, VanBogelen RA Overcoming technical variation and biological variation in quantitative proteomics. Proteomics 2003, 3:1912-1919.

Publish with Bio Med Central and every scientist can read your work free of charge

"BioMed Central will be the most significant development for disseminating the results of biomedical research in our lifetime. "

Sir Paul Nurse, Cancer Research UK

Your research papers will be:

- available free of charge to the entire biomedical community

- peer reviewed and published immediately upon acceptance

- cited in PubMed and archived on PubMed Central

- yours - you keep the copyright

Submit your manuscript here:

http://www.biomedcentral.com/info/publishing_adv.asp
BiolMedcentral 